\title{
ORGANOCHLORINE INSECTICIDES (DDT AND HEPTACHLOR) IN DRY FISH AVAILABLE IN BANGLADESH: SEASONAL TRENDS AND SPECIES VARIABILITY
}

\author{
MD. NURUL HUDA BHUIYAN ${ }^{I^{*}}$, HABIBUR RAHMAN BHUIYAN ${ }^{1}$, K. K. NATH ${ }^{1}$, KABIR AHMED ${ }^{1}$, MD. TARIQUL \\ HASSAN AND MD. NAZRUL ISLAM BHUIYAN ${ }^{2}$
}

\author{
${ }^{1}$ BCSIR Laboratories Chittagong, Chittagong-4220, Bangladesh, \\ ${ }^{2} I F S T$, BCSIR, Dhaka, Bangladesh. \\ (Received: September 8, 2008 - Accepted: April 27, 2009)
}

\begin{abstract}
The concentrations of organochlorine insecticides DDT (Dichloro diphenyl trichloro ethane) and Heptachlor were investigated to estimate the current status of insecticides used in dry fish in different seasons and different species. Six most popular species of dry fishes namely Bombay duck (Loittya), Ribbon fish (Chhuri), Shrimp (Chingri), Hilsha shed (Ilish), Chinese pomfret (Rupchanda) and Indian salmon (Lakhua) were collected from Asadgonj (whole sell market for dry fish) of Chittagong, Bangladesh at different seasons, six samples at winter season (December) and six same samples at rainy season (July). The range of DDT concentration at winter was found $3.6 \mathrm{ug} \mathrm{kg}-1$ to $250.8 \mathrm{ug} \mathrm{kg}-1$ and at rainy season the range of concentration was found $11.1 \mathrm{ug} \mathrm{kg}-1$ to $1107.4 \mathrm{ug} \mathrm{kg}-1$. The range of Heptachlor concentration at winter was found $0.4 \mathrm{ug} \mathrm{kg}-1$ to $2.5 \mathrm{ug} \mathrm{kg}-1$ and at rainy season was found $1.1 \mathrm{ug} \mathrm{kg}-1$ to $37.8 \mathrm{ug} \mathrm{kg}-1$. The concentrations of DDT and Heptachlor were much higher in the samples of rainy season than the same samples of the winter.
\end{abstract}

Keywords: Dry fish, Concentration, organochlorine insecticides, DDT(Dichloro diphenyl trichloro ethane), Heptachlor, Season.

\section{INTRODUCTION}

Dry fish (SHUTKI in Bengali), is the most popular food item of Bangladesh. It is the main protein source in many areas of this country and recently exported abroad where the main consumers are immigrants and workers of the third world country. The coastal areas, rivers and several haors are famous for producing dry fish, which is dried under the sun from mid October to mid April. Huge amount of fish catches from fresh and marine water during winter season. During this time the Bay of Bengal, the coastal crisscross channels and other depressions remain calm and quiet and as a result fishing activities are strengthened and huge fishes are harvested during this period than the other seasons. The necessity to cultivate dry fish looms up when huge quantity of fresh fish caught everyday remains unsold because of shortage of customers and cannot be sent to the towns or the metropolis on a daily basis either for shortage of transport or fish traders not willing to pay the right amount of money. As a result winter is considered to be the peak season for drying fish. For long conservation of fish by drying is common practice in Bangladesh. To protect the dry fishes from infestation they use insecticides whatever they are getting within their reach. Studies on the conservation of dry fish showed that a mixture of organochlorine (DDT \& Heptachlor) is used in dry fish in Bangladesh ${ }^{1}$. Some analysis in Bangladesh shows alarming pollutants in fish like DDT and heptachlor ${ }^{2}$. Many people call DDT as white powder and in Kuakata (a fish processing zone in Bangladesh) high level of DDT powder (white powder) is used on dry fish though as a member of the United Nations, Bangladesh banned the 'dirty dozen' in $1997^{3}$.

In Bangladesh at present all POPs (Persistent Organic Pollutants) like DDT $\&$ Heptachlor import and production has been banned but at least five POPs pesticides including DDT are still in use under a different name or label. There are no central registers or lists in Bangladesh, though some intergovernmental organizations like the Food and Agricultural Organization (FAO) and the World Bank have begun to assemble aggregate use data. Since country-specific data were not found this does not tell enough about usage to know specifically where and how much of these compounds are being used. The formal first import of DDT \& Heptachlor was recorded in 1987 and the import was closed in 1997 with the banning of heptachlor 40WP in Bangladesh. Surprisingly, DDT, the most commonly used POPs pesticide in Bangladesh particularly in public health was never registered ${ }^{4}$. Therefore, to speak documentarily, at present there is no legal use of any POP pesticides in Bangladesh. The Government of Bangladesh signed the Stockholm Convention on POPs on 23 May 2001. A national implementation plan is already underway from September 2002 for the POPs through the assistance of UNEP. The Department of Environment, a member of Pesticide Technical Advisory Committee (PTAC) controls the pesticide registration scheme in Bangladesh. No pesticides and insecticides are registered without reviewing the available Toxicological and Eco-toxicological information of the candidate pesticide. However, there is no specific legislation for controlling the production and use of hazardous industrial chemicals ${ }^{5}$.

In the last 50 years, people have generated 80,000 types of chemicals. Of them, there are organic chemical pollutants known as 'dirty dozen', which is very harmful to human bodies ${ }^{3}$. These pollutants constantly enter bodies through food and drink and cripple different limbs. Among the dirty dozen the chlorinated hydrocarbons (organochlorine compounds) were the first generation of pesticides called wonder drug, introduced following the Second World War which comprise DDT, Dieldrin, Heptachlor and others. They are designed to kill insects and which, as broad-spectrum poisons. DDT can transfer from generation to generation through breast milk ${ }^{6}$. In areas where it is used for malaria control, infants can be exposed via breastmilk in levels that exceed the W.H.O'S acceptable daily intake value for DDT $^{7,8}$. It is classified as "moderately toxic" by the US National Toxicological Program and "moderately hazardous" by WHO, based on the rat oral LD50 of $113 \mathrm{mg} / \mathrm{kg}^{9}$. Farmers exposed to DDT occupationally have an increased incidence of non-allergic asthma ${ }^{10}$. Organochlorine compounds in general have been linked to diabetes ${ }^{11}$. EPA classified it as a class B2 probable human carcinogen ${ }^{12}$. A study of malaria workers who handled it occupationally found an elevated risk of cancers of the liver and biliary $\operatorname{tract}^{13}$. Exposure to it before puberty increases the risk of breast cancer later in $l^{1 i f e}{ }^{14}$. On the other hand Heptachlor has been shown to bioaccumulates in fish and cattle. Most of the heptachlor that is swallowed is absorbed into blood. It can pass directly from a mother's blood to an unborn baby through the placenta. Animals fed heptachlor throughout their lifetime had more liver tumors than animals that ate food without heptachlor. EPA has classified heptachlor as a probable human carcinogen (B2) and established an oral cancer slope factor of $4.5 \mathrm{per} \mathrm{mg} / \mathrm{kg}$-day ${ }^{15}$.

The most significant properties of the organochlorine insecticides are their extreme lipophilic nature and resistance to biodegradation, which results in their accumulation and concentration in fatty tissues and their extreme persistence in environment ${ }^{16}$. Among the insecticides DDT is a commercial organochlorine insecticide that has been widely used on agricultural crops as well as for vector control ${ }^{17}$. DDT and its by-products can persist in soil and sediments for more than 15 years and are known to bio accumulate in animal tissues. DDT had been banned for all uses in 49 countries and restricted to vector control in $23^{18}$. The half-life of DDT in humans is approximately 4 years ${ }^{19}$. Heptachlor is another organochlorine cyclodiene pesticide that has been used to control termites and as an insecticide on seed grains and food crops. Heptachlor epoxide, the main metabolite of heptachlor, is extremely persistent in soil. In some cases, trace amounts of heptachlor epoxide have been found in soil 14-16 years after application ${ }^{20}$. Plants can draw heptachlor epoxide directly from the soil, and the chemical bioaccumulates in animals. It has been banned or restricted in more than 60 countries $^{21}$. A study showed that countries have restricted and banned heptachlor; levels detected in breast milk have dropped, often by more than 10 -fold ${ }^{22}$. But another studies showed that in the United States, levels in the Southeast were nearly double the levels in the rest of the country during the period when it was still used ${ }^{23}$. However, some of these countries still permit its use for termite and other pest control, and many developing nations still use for agricultural purposes ${ }^{24}$. Despite the imposition of a ban on use in the United States in 1988, U.S. customs data showed that it was exported in large quantities through $1994^{25}$.

The objectives of this study were to detection and determination of the 
concentration level of insecticides (DDT \& Heptachlor) in dry fish at winter and rainy season, used for conservation of dry fish and to elucidate the variation of concentration level of insecticides due to fish species. No studies of OCPs (DDT \& Heptachlor) in the dry fish of Bangladesh to estimate the current status of insecticides used in dry fish in different seasons and different species have been carried out.

\section{EXPERIMENTAL}

\section{Sampling}

Six most popular dry fish samples namely Bombay duck (Loittya), Ribbon fish (Chhuri), Shrimp (Chingri), Hilsha shed (Ilish), Chinese pomfret (Rupchanda) and Indian salmon (Lakhua) were collected from Asadgonj (whole sell market for dry fish) of Chittagong, Bangladesh at winter season (December) and another six samples of same species from same place were collected at rainy season (July). Total number of samples was twelve.

The control samples of six different fishes were collected from drying yards of Sonadia island (a fish processing zone of Bangladesh) that are known sample treated with no insecticides and taken in to account as blank.

\section{Apparatus}

Mincer fish chopper ( Weisser No. $81 \mathrm{~K}$ ), Soxhlet extractor, separatory funnels $(500 \mathrm{ml} \& 200 \mathrm{ml})$, Chromatographic tube $(20 \mathrm{~mm}$ i.d. $50 \mathrm{~cm}$ long), sample concentrator (Techne dry block DB.3), round bottomed flask $(500 \mathrm{ml}$ \& $100 \mathrm{ml}$ ), volumetric flask (50 $\mathrm{ml} \& 10 \mathrm{ml})$, Gas Chromatograph (GC-14B, Shimadzu), syringe( $10 \mu 1$, Hamilton Co.).

\section{Reagents}

Acetone, Diethyl ether, Dimethyl Formamide saturated with petroleum ether, n-hexane, petroleum ether $\left(30-60^{\circ} \mathrm{C}\right)$, petroleum ether $\left(30-60^{\circ} \mathrm{C}\right)$ saturated with Dimethyl Formamide, eluting mixture I ( petroleum ether + diethyl ether $94: 6 \mathrm{v} / \mathrm{v})$, standard solutions, eosin solution $(2 \mathrm{mg}$ in $100 \mathrm{ml})$, sodium sulphate solution $\left(2 \mathrm{~g} / 100 \mathrm{ml} \mathrm{Na} \mathrm{SO}_{2} 10 \mathrm{H}_{2} \mathrm{O}\right)$, sodium sulphate anhydrous ( heated for at least $2 \mathrm{~h}$ at $550^{\circ} \mathrm{C}$ ), Florisil $60-100$ mesh (heated for at least $2 \mathrm{~h}$ at $550^{\circ} \mathrm{C}$, cool \& stored in tightly stoppered container, prior to use heated for at least $5 \mathrm{~h}$ at $130^{\circ} \mathrm{C}$, cool \& add $5 \% \mathrm{w} / \mathrm{w}$ water, shake this mixture for at least $20 \mathrm{~min}$ and stored in a container for at least $10 \mathrm{~h}$ ), cotton wool.

HPLC grade solvents purchased from MERCK, Germany and DDT (98.3\%) \& Heptachlor (97.7\%) standards obtained from Sigma, USA were used for the analysis.

Sample preparation: All the samples are finely comminuted in a mincer; heating of the samples during comminuting is avoided by briefly chopping several times ${ }^{26}$.

\section{Extraction}

Triturate a sample of $25 \mathrm{~g}$, with Sodium Sulphate to dry, powdery mixture, with the aid of an extraction thimble; extract the mixture exhaustively with Petroleum Ether in Soxhlet apparatus. Concentrate just to dryness the extract solution by a concentrator and dilute to $25 \mathrm{ml}$ with Petroleum Ether saturated with Dimethyl Formamide ${ }^{26}$.

\section{Clean up}

Clean up was done in two steps ${ }^{26}$

\section{a) Dimethylformamide-petrolium ether partition}

Transfer the solution (dissolved in $25 \mathrm{ml}$ Petroleum Ether saturated with Dimethyl Formamide) to $250 \mathrm{ml}$ separatory funnel. Rinse the flask with small portion of a previously measured amount of $75 \mathrm{ml}$ Dimethyl Formamide. Then add the remainder of the Dimethyl Formamide to the separatory funnel, and shake vigorously for $1 \mathrm{~min}$. Drain the Dimethyl Formamide phase, and again extract the Petroleum Ether phase with $10 \mathrm{ml}$ Dimethyl Formamide. Transfer the combined Dimethyl Formamide phases to a $500 \mathrm{ml}$ separatory funnel, and add $200 \mathrm{ml}$ sodium sulphate solution. Add a few drops of eosin solution to achieve better recognition of phase separation in the subsequent partition. Then extract successively with a $40 \mathrm{ml}$ portion and three $25 \mathrm{ml}$ potions of petroleum ether for $1 \mathrm{~min}$ each time. Wash the combined petroleum ether phases with 10 $\mathrm{ml}$ water, dry on sodium sulphate, filter through a cotton wool plug, add $5 \mathrm{ml}$ $\mathrm{n}$-hexane, and concentrate to approx. $5 \mathrm{ml}$.

\section{b) Florisil column chromatography}

About half filled a chromatographic tube with petroleum ether, and sprinkle with $30 \mathrm{~g}$ Florisil in small portions through a funnel with stopcock open, tapping the column in the process. Cover the Florisil with an approx. 2 $\mathrm{cm}$ layer of sodium sulphate. Drain the supernatant solvent to the top of the column packing. Pipette the sample solution on to the column. Let the solution percolate to a level of 1-2 mm above the top of the column. Then rinse the flask with small portions of eluting mixture I, add the rinsings to the column, and also let them percolate to a level of 1-2 mm above the top of the column. Next eluate the column with the remainder of the total $200 \mathrm{ml}$ amount of eluting mixture I, at a flow rate of about $5 \mathrm{ml} / \mathrm{min}$. Concentrate the eluate near to dry and add $5 \mathrm{ml} \mathrm{n}$ - hexane to the eluate. Again concentrate the eluate to $1 \mathrm{ml}$.

Sample analyses: The DDT \& Heptachlor residues were analyzed by GC14B, Shimadzu with an electron capture detector (ECD), a manual sampler and GC solution software. A column of $3.1 \mathrm{~m}$ x $3.2 \mathrm{~mm}$; I.D glass spiral; stationary phase silicon OV-17, $5 \%$, aging $300^{\circ} \mathrm{C}$, support chromosorb-W-AW-DMCS, mesh $80 / 100,1 \mu \mathrm{m}$ film thickness was used for the chromatographic separation of insecticides. The temperature was fixed for the injector at $250^{\circ} \mathrm{C}$, column at $280^{\circ} \mathrm{C}$, detector at $280^{\circ} \mathrm{C}$. The carrier gas was nitrogen with a $60 \mathrm{ml} / \mathrm{min}$-flow rate. $1.0 \mathrm{ul}$ sample was injected for each run and the running time was $25 \mathrm{~min}$. Standards' peak were identified by injecting high concentration of the standard ( $0.5 \mathrm{mg} \mathrm{kg}-1 \& 0.25 \mathrm{mg} \mathrm{kg}-1$ ) and the retention time for DDT \& Heptachlor were determined. Then calibration was done at 3 points $(25 \mathrm{ug} \mathrm{kg}-1,50 \mathrm{ug}$ $\mathrm{kg}-1$ and $100 \mathrm{ug} \mathrm{kg-1)}$ by composite stock standard solution. GC system was calibrated using external standard technique. Individual standard stock solution $(100 \mathrm{mg} / \mathrm{l})$ was prepared by weighing appropriate amounts of active ingredients in a brown bottle with a Teflon-lined screw cap and dissolving the weighed standard in HPLC grade hexane. Stock standard solution was used to prepare primary dilution standards. Appropriate volume of each individual stock solution was taken in a volumetric flask and mixed the solutions to obtain composite stock standard solution.

\section{Analytical quality control}

Gas chromatograph equipped with ECD was checked for linearity. Instrumental limit of detection for GC-ECD was $1.0 \mathrm{ug} / 1$ for organochlorine pesticides. An aliquot of dry fish samples which were collected as blank and treated exactly as a sample including exposure to all glassware, equipments, solvents and reagents used with the sample matrix. No analyte peak was detected in laboratory reagent blank. Nine fortified sample matrixes (three for each concentration) were prepared to which known quantities of the pesticides (25 ug kg-1, 50 ug kg-1 and 100 ug kg-1) were spiked in the laboratory.These laboratory fortified matrixes were analyzed exactly like the samples. Extraction and clean up were done as mentioned and the recoveries from untreated control samples of dry fish fortified with the analyzed compounds at level of 25 ug kg-1, 50 ug kg-1 and 100 ug kg-1 were $96-100 \%$ for Heptachlor and $98-100 \%$ for DDT. Prior to injection of the first sample solution, a standard solution followed by a blank was injected at least three times to check the operating conditions and the constancy of the detector signals. Further linearity of the ECD signal was checked by injecting serial dilutions of DDT \& Heptachlor. A standard solution injected after at least every other sample solution so that any alterations of the gas chromatographic system recognized due to column contamination.

\section{RESULTS AND DISCUSSION}

Twelve samples of six fish species namely Bombay duck (Loittya), Ribbon fish (Chhuri), Shrimp (Chingri), Hilsha shed (Ilish), Chinese pomfret (Rupchanda) and Indian salmon (Lakhua) were analyzed to detect DDT \& Heptachlor at winter (December) and at rainy season (July). The results obtained are alarming for Bangladesh. All of the samples contained organochlorine insecticides (except Ribbon fish at winter season Heptachlor was not detected) are shown in Table-1 and the chromatogram of two more representative of the samples are shown in fig (1-4). 


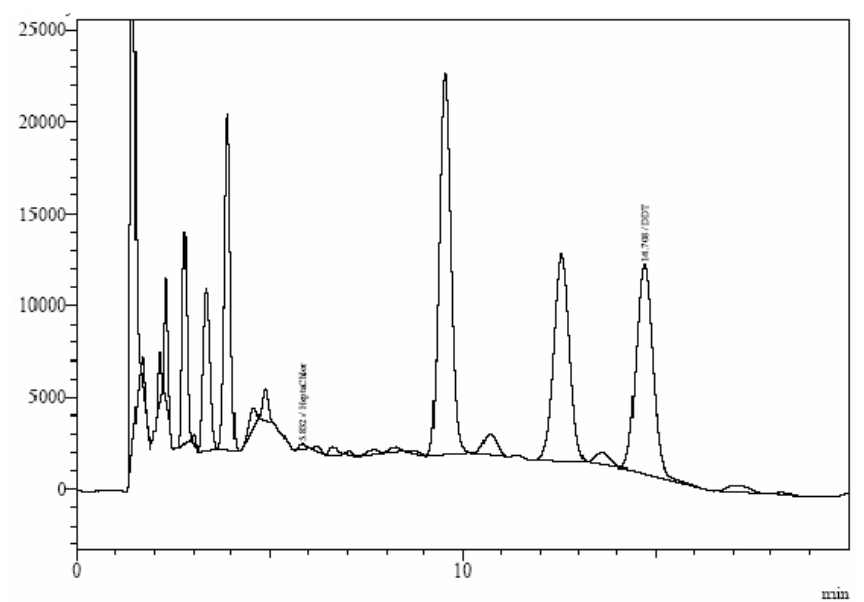

Figure 1.- Bombay duck, Winter season.

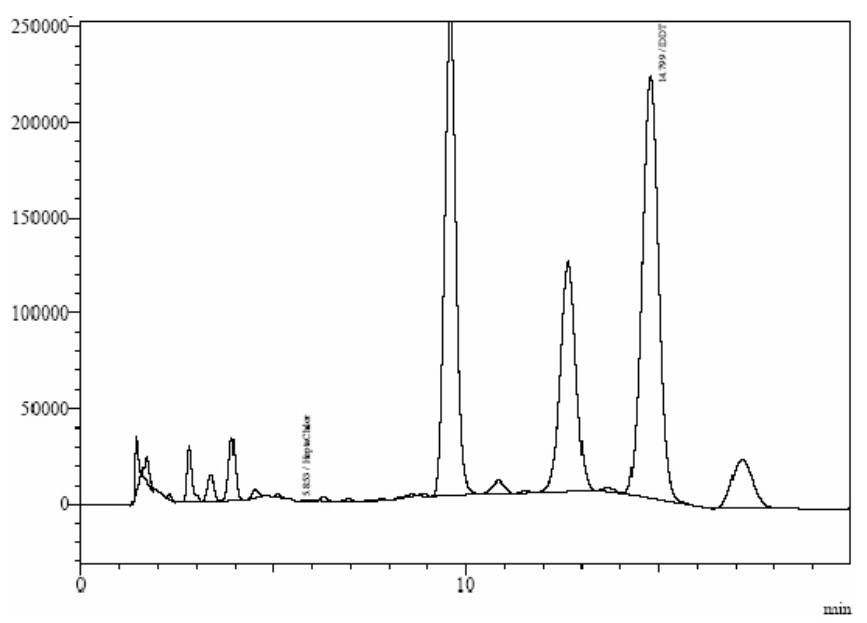

Figure 3.- Chinese pomfret, Winter season.

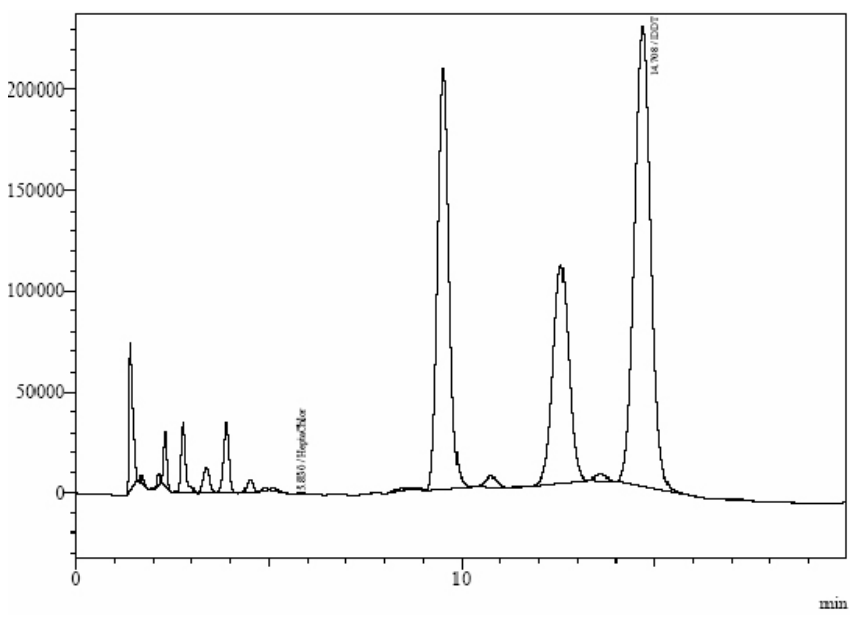

Figure 2.- Bombay duck, Rainy season.

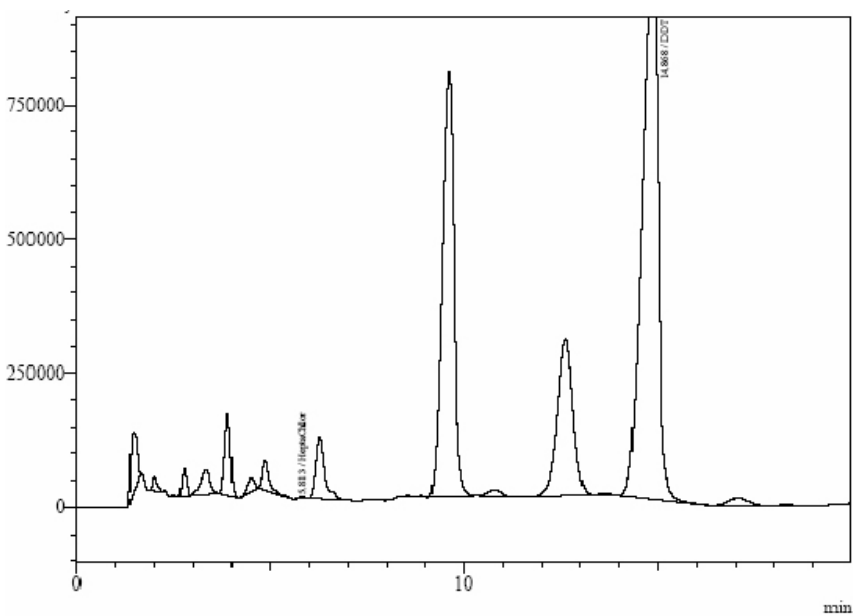

Figure 4.- Chinese pomfret, Rainy season.

Fig: (1-4).- showed different chromatograms of DDT and Heptachlor for two species in different seasons, are representatives of other samples of different species.

Table -1.- DDT (Dichloro diphenyl trichloro ethane) \& Heptachlor concentrations in the dry fish samples (the concentrations are in ug kg-1 unit).

\begin{tabular}{|c|c|c|c|}
\hline Name of the samples & Name of insecticides & Winter season & Rainy season \\
\hline \multirow{2}{*}{ Bombay duck (Loittya) } & Heptachlor & 0.4 & 1.1 \\
\cline { 2 - 4 } & DDT & 13.1 & 257.2 \\
\hline \multirow{2}{*}{ Ribbon fish (Chhuri) } & Heptachlor & 3.6 & 556.3 \\
\cline { 2 - 4 } & DDT & 0.9 & 2.9 \\
\hline \multirow{2}{*}{ Shrimp (Chingri) } & Heptachlor & 21.6 & 369.6 \\
\hline \multirow{2}{*}{ Hilsha shed (Ilish) } & DDT & 1.1 & 2.7 \\
\cline { 2 - 4 } & Heptachlor & 152.5 & 4.0 \\
\hline \multirow{2}{*}{ Chinese pomfret (Rupchanda) } & DDT & 2.5 & 1107.4 \\
\cline { 2 - 4 } & Heptachlor & 250.8 & 2.5 \\
\hline \multirow{2}{*}{ Indian salmon (Lakhua) } & DDT & 37.8 & 233.7 \\
\cline { 2 - 4 }
\end{tabular}

*ND - Not Detected, Parenthesis indicates the Bengali name. 
The concentration of DDT at winter season for low priced dry fishes (Bombay duck, Ribbon fish and Shrimp) varied from minimum 3.6 ug kg-1 (Ribbon fish) to maximum $21.6 \mathrm{ug} \mathrm{kg-1}$ (Shrimp) and the concentration for the highly priced dry fishes (Hilsha shed, Chinese pomfret and Indian salmon) varied from $11.1 \mathrm{ug} \mathrm{kg-1}$ (Indian salmon) to maximum $250.8 \mathrm{ug} \mathrm{kg}-1$ (Chinese pomfret). At rainy season the concentration of DDT for low priced dry fishes varied from $257.2 \mathrm{ug} \mathrm{kg-1}$ (Bombay duck) to maximum $556.3 \mathrm{ug} \mathrm{kg}-1$ (Ribbon fish) and the concentration for highly priced dry fishes were varied from minimum $233.7 \mathrm{ug} \mathrm{kg-1}$ (Indian salmon) to maximum $1107.4 \mathrm{ug} \mathrm{kg}-1$ (Chinese pomfret). The concentrations of DDT were generally higher in costly dry fishes in winter season but at rainy season DDT concentrations were much higher than those of winter season for all the dry fish samples.

The concentration of Heptachlor at winter season for Ribbon fish, a low priced dry fish, was not detected and the concentration of other two low priced dry fishes were 0.4 ug kg-1 (Bombay duck) and 0.9 ug kg-1 (Shrimp) and the concentration for the highly priced dry fishes varied from minimum $1.1 \mathrm{ug} \mathrm{kg}-1$ (Hilsha shed) to maximum $37.8 \mathrm{ug} \mathrm{kg}-1$ (Indian salmon). At rainy season the concentration of Heptachlor for low priced dry fishes varied from $1.1 \mathrm{ug} \mathrm{kg-1}$ (Bombay duck) to maximum $4.1 \mathrm{ug} \mathrm{kg-1}$ (Ribbon fish) and the concentration for highly priced dry fishes were varied from minimum $2.5 \mathrm{ug} \mathrm{kg}-1$ (Indian salmon) to maximum $4.0 \mathrm{ug} \mathrm{kg}-1$ (Chinese pomfret). The concentrations of Heptachlor were generally more or less constant in all samples for both seasons except Indian salmon. Although Indian salmon is highly priced dry fish and it contained lower amount of DDT (11.1 ug kg-1) at winter season but it contained exceptionally higher amount of Heptachlor (37.8 ug kg-1) at that season..

\section{CONCLUSIONS}

From the study, we can say that, the fisher men and the stocker used DDT $\&$ Heptachlor in the dry fishes sold in both winter and rainy season but at rainy season the amount is much higher than the winter. It is also higher in the costly fishes. It also found that the fishermen do not dry fishes properly due to loss of weight i.e., the fishermen want more profit selling the dry fishes in weight, preparably they do this for high cost fishes such as Hilsha shed, Chinese pomfret and Indian salmon. As a signatory of the Stockholm Convention, the Government of Bangladesh is required to take action to generate general awareness of consequences of DDT \& Heptachlor. To initiate comprehensive mass awareness campaign on POPs need of financial and technical support to encourage action research activities. A variety of chemical and non-chemical alternatives are available for POPs in Bangladesh. Beside the government the stocker should dry correctly and should pack carefully so that the fish can not absorb moisture in monsoon. The other way of preservation can follow such as freezing, canning and curing.

\section{REFERENCES}

1. M. N. H. Bhuiyan, H. R. Bhuiyan, M. Rahim, K. Ahmed, K.M. F. Haque, M. T. Hassan, M. N. I. Bhuiyan. Bangladesh J Pharmacol. 3, 114, (2008).

2. BCAS.Bangladesh Env. News Letter; n. 6, v 2, Dhaka, Bangladesh 1990. Available at http://www.sos-arsenic.net/english/export/1.html.

3. S. Barua. Escaping from organic chemical pollutants, The new nation, Internet Edition. November 19, 2007. Available at http://nation.ittefaq. $\underline{\mathrm{com} / \mathrm{rss} . \mathrm{xml}}$
4. ESDO (Environment and Social Development Organization).Country Situation Report on Persistent Organic Pollutants in Bangladesh, 5, 2005.

5. UNEP. United Nations environment program chemicals, Indian Ocean regional report. UNEP Chemicals is a part of UNEP's Technology, Industry and Economics Division, 15, 2002.

6. G. Solomon, P. Weiss. Healthy Milk, Healthy Baby. New York:Natural Resources Defense Council 2001. Available at http://www.nrdc.org/ breastmilk.

7. H. Bouwman, B. Sereda, H.M. Meinhardt. Environ. Pollut. 144 (3), 902 , (2006).

8. W. J. Ntow, L. M. Tagoe, P. Drechsel, P. Kelderman, H. J. Gijzen, E. Nyarko. Environ. Res. 106 (1), 17, (2008).

9. WHO (World Health Organization). Brit J Psychiat. 187, (2005).

10. Anthony, J. Brow. J. Am Med Assoc. 162 (9), 890, (2007).

11. O. A. H. Jones, M. L. Maguire, J. L Griffin. The Lancet. 371, 287 , (2008).

12. US EPA. Integrated Risk Information System p, p'Dichlorodiphenyltrichloroethane (DDT) (CASRN 50-29-3) II.A.1. Weight-of-Evidence Characterization. 1987, 52(130), 25720.

13. W. J. Rogan, A. Chen. Lancet. 366 (9487), 763, (2005).

14. R.W. Clapp, M.M. Jacobs, E.L Loechler. Rev Environ Health, 23 (1), 1, (2008).

15. LDWG (Lower Duwamish Waterway Group). LDW RI: Baseline HHRA Attachment 4. Toxicological Profiles for Chemicals of Potential Concern, 9, 2007.

16. S. R. Tannenbaum. Nutritional and safety aspects of food processing (vol.-6), Marcel Dekker, Inc. New York and Basel, USA, 300, 1979.

17. ATSDR (Agency for Toxic Substances and Disease Registry). ToxFAQs for DDT, DDE, and DDE. Atlanta, GA: US Department of Health and Human Services, 39, (1995).

18. PANNA. Demise of the Dirty Dozen Chart. San Francisco, CA: Pesticide Action Network North America, 24, (1995).

19. K. Noren, D. Meironyte. Chemosphere. 40, 1111, (2000).

20. Extoxnet. Pesticide Information Profile. Heptachlor. Corvallis, OR:Oregon State University (1996). Available at http://ace.orst.edu/info/extoxnet/ pips/heptachl.htm.

21. WHO.Heptachlor Health and Safety Guide. Health and Safety Guide 14. Geneva:World Health Organization, 58, (1988).

22. A. A. Jensen, S.A. Slorach. Chemical Contaminants in Human Milk. Boca Raton, FL: CRC Press, 1, (1991).

23. E. Savage. Am J Epidemiol. 113, 413, (1981).

24. F. Noronha. Persistent organic pollutants pervade Asia. Environment News Service (1998). Available at http:// ens.lycos.com/ens/nov98/1998L-1123-03.html.

25. PANNA. Velsicol Ceases Production of Chlordane and Heptachlor. PANUPS. San Francisco:Pesticide Action Network North America, (1997). Available at http:// www.igc.org/panna/resources/_pestis/ PESTIS.1997.43.ht.

26. H. Peter, H. Zeumer. Manual of pesticides residue Analysis, vol.-I, working group analysis. Pesticide commission, Germany, VCH, 298, 1987. 